\title{
THE MISSION AS A FRONTIER INSTITUTION IN THE SPANISH- AMERICAN COLONIES
}

HERBERT E. BOLTON

REPRINTED FROM THE

\section{American fistorial geview}





\section{8}

[Reprinted frum The American Histurical. Review, Vol. XXIII, No. I, Oct., 1917.]

\section{THE MISSION AS A FRONTIER INSTITUTION IN THE SPANISH-AMERICAN COLONIES}

Of the missions in Spanish America, particularly those in California, much has been written. But most of what has been produced consists of chronicles of the deeds of the Fathers, polemic discussions by sectarian partizans, or sentimental effusions with literary, edifying, or financial intent. They deal with the heroic exploits of individuals, with mooted questions of belief and practice, or with the romance that hovers round the mission ruins. All this is very well, and not to be ridiculed, but it is none the less true that little has been said of these missions in their relation to the general Spanish colonial policy, of which they were an integral and a most important part. Father Engelhardt's learned books are a notable exception, but his view is confined closely to California, whereas the mission, in the Spanish colonies, was an almost universal establishment.

One of the marvels in the history of the modern world is the way in which that little Iberian nation, Spain, when most of her blood and treasure were absorbed in European wars, with a handful of men took possession of the Caribbean archipelago, and by rapid yet steady advance spread her culture, her religion, her law, and her language over more than half of the two American continents, where they still are dominant and still are secure-in South America, Central America, and a large fraction of North America, for fifty million people in America to-day are tinged with Spanish blood, still speak the Spanish language, still worship at the altar set up by the Catholic kings, still live under laws essentially Spanish, and still possess a culture largely inherited from Spain.

These results are an index of the vigor and the virility of Spain's frontier forces; they should give pause to those who glibly speak of Spain's failure as a colonizing nation; and they suggest the importance of a thoughtful study of Spain's frontier institutions and methods. Professor Turner has devoted his life to a study of the Anglo-American frontier, and rich has been his reward. Scarcely less conspicuous in the history of the Western world than the advance of the Anglo-American frontier has been the spread of Spanish culture, and for him who interprets, with Turner's insight, the methods 
and the significance of the Spanish-American frontier, there awaits a recognition not less marked or less deserved.

Whoever essays this task, whoever undertakes to interpret the forces by which Spain extended her rule, her language, her law, and her traditions, over the frontiers of her vast American possessions, must give close attention to the missions, for in that work they constituted a primary agency. Each of the colonizing nations in America had its peculiar frontier institutions and classes. In the French colonies the pioneers of pioneers were the fur-trader and the missionary. Penetrating the innermost wilds of the continent, one in search of the beaver, the other in quest of souls to save, together they extended the French domains, and brought the savage tribes into friendly relations with the French government, and into profitable relations with the French outposts. In the English colonies the fur-trader blazed the way and opened new trails, but it was the backwoods settler who hewed down the forest, and step by step drove back the Indian with whom he did not readily mingle. In the Spanish colonies the men to whom fell the task of extending and holding the frontiers were the conquistador, the presidial soldier, and the missionary.

All of these agents were important; but in my study of frontier institutions in general, and in my endeavor in particular to understand the methods and forces by which Spain's frontiers were extended, held, and developed, I have been more and more impressed with the importance of the mission as a pioneering agency. Taking for granted for the moment its very obvious religious aspects; I shall here devote my attention more especially to the mission's political and social meaning. My point of view embraces all of New Spain -all of the Spanish colonies, indeed-but more particularly the northern provinces, from Sinaloa to Texas, from Florida to California. My conclusions are based on the study of documents, unprinted for the most part, which have been gathered mainly from the archives of Mexico and Spain.

The functions of the mission, from the political standpoint, will be better understood if it is considered in its historical relations. The central interest around which the mission was built was the Indian. In respect to the native, the Spanish sovereigns, from the outset, had three fundamental purposes. They desired to convert him, to civilize him, and to exploit him: To serve these three purposes, there was devised, out of the experience of the early conquerors, the encomienda system. It was soon found that if the savage were to be converted, or disciplined, or exploited, he must 
be put under control. To provide such control, the land and the people were distributed among Spaniards, who held them in trust, or in encomienda. The trustee, or encomendero, as he was called, was strictly charged by the sovereign, as a condition of his grant, to provide for the protection, the conversion, and the civilization of the aborigines. In return he was empowered to exploit their labor, sharing the profits with the king. To provide the spiritual instruction and to conduct schools for the natives-for Indian schools were actually prescribed and maintained-the encomenderos were required to support the necessary friars, by whom the instruction was given. Thus great monasteries were established. in the conquered districts.

But the native had his own notions, especially about being exploited, and he sometimes fled to the woods. It was soon discovered, therefore, that in order properly to convert, instruct, and exploit the Indian, he must be kept in a fixed place of residence. This need was early reported to the sovereigns by encomenderos and friars alike, and it soon became a law that Indians must be congregated in pueblos, and made to stay there, by force if necessary. The pueblos were modelled on the Spanish towns, and were designed not alone as a means of control, but as schools in selfcontrol as well.

Thus, during the early years of the conquest, the natives were largely in the hands of the encomenderos, mainly secular landholders. The friars, and afterward the Jesuit priests, came in great numbers, to preach and teach, but they lacked the authority of later days. In 1574 there were in the conquered districts of Spanish America nearly nine thousand Indian towns, containing about one and a half million adult males, representing some five million people, subject to tribute. These nine thousand towns were encomiendas of the king and some four thousand encomenderos.

The encomienda system then, by intention, was benevolent. It was designed for the conversion and the civilization of the native, as well as for the exploitation of his labor. But the flesh is weak, and the system was abused. The obligations to protect, convert, and civilize were forgotten, and the right to exploit was perverted into license. Practical slavery. soon resulted, and the encomienda system became the black spot in the Spanish-American code. Philanthropists, led by Las Casas, begged for reform; abuses were checked, and encomiendas were gradually, though slowly, abolished.

This improvement was made easier by the decreasing attractiveness of encomiendas, as the conquest proceeded to the outlying dis- 
tricts. The semi-civilized Indians of central Mexico and Peru had been fairly docile, had had a steady food supply and fixed homes, were accustomed to labor, and were worth exploiting. The wilder tribes encountered later-the Chichimecos, as they were called-were hostile, had few crops, were unused to labor, had no fixed villages, would not stand still to be exploited, and were hardly worth the candle. Colonists were no longer so eager for encomiendas, and were willing to escape the obligation to protect and civilize the wild tribes, which were as uncomfortable burdens, sometimes, as cubtigers in a sack. 'Moreover, the sovereigns, with increasing emphasis, forbade the old-time abuses of exploitation, but as strongly as before adhered to the ideal of conversion and civilization. Here, then, was a larger opening for the missionary, and to him was entrusted, or upon him was thrust, consciously or unconsciously, not only the old work of conversion, but a larger and larger element of responsibility and control. On the northern frontier, therefore, among the roving tribes, the place of the discredited encomendero was largely taken by the missionary, and that of the encomienda by the mission, the design.being to check the evils of exploitation, and at the same time to realize the ideal of conversion, protection, and

\section{- civilization.}

These missionaries became a veritable corps of Indian agents, serving Doth Church and State. The double caparity in which they - served was ride sier and more natural by the close union between Church and State in Spanish America, where the king exercised the : real patronato, and where the viceroys were sometimes archbishops as well.

Under these conditions, in the seventeenth and eighteenth centuries, on the expanding frontiers of Spanish America, missions became well-nigh universal. In South America the outstanding examples were the Jesuit missions in Paraguay. ${ }^{*}$ Conspicuous in North America were the great Franciscan establishments in Alta California, the last of Spain's conquests. Not here alone, however, but everywhere on the northern frontier they played their partin Sinaloa, Sonora, and Lower California ; in Chihuahua, Coahuila, Nuevo León, and Nuevo Santander; in Florida, New Mexico, Texas, and Arizona. If there were twenty-one missions in California, there were as many in Texas, more in Florida, and twice as many in New Mexico. At one time the California missions had over thirty thousand Indians under instruction; but a century and a half earlier the missions of Florida and New Mexico each had an equal number. 
The missionary work on the northern frontier of New Spain was conducted chiefly by Franciscans, Jesuits, and Dominicans. The northeastern field fell chiefly to the Franciscans, who entered Coahuila, Nuevo León, Nuevo Santander, New Mexico, Texas, and Florida.' To the Northwest came the Jesuits, who, after withdrawing from Florida, worked especially in Sinaloa, Sonora, Chihuahua, Lower California, and Arizona. In 1767 the Jesuits were expelled from all Spanish America, and their. places taken by the other orders. To Lower California came the Dominicans, to Alta California the Franciscans of the College of San Fernando, in the City of Mexico.

The missions, then, like the presidios, or garrisons, were characteristically and designedly frontier institutions, and it is as pioneer agencies that they must be studied. This is true whether they be considered from the religious, the political, or the social standpoint. As religious institutions they were designed to introduce the Faith among the heathen. Having done this, their function was to cease. Being designed for the frontier, they were intended to be temporary. As soon as his work was finished on one frontier, the missionary was expected to move on to another. In the theory of the law, within ten years each mission must be turned over to the secular clergy, and the common mission lands distributed among the Indians. But this law had been based on experience with the more advanced tribes of Mexico, Central America, and Peru. On the northern frontier, among the barbarian tribes, a longer period of'tutelage was always found necessary.

The result, almost without fail, was a struggle over secularization, such as occurred in California. So long as the Indians were under the missionaries, their lands were secure from the landgrabber. The land-grabber always, therefore, urged the fulfillment of the ten-year law, just as the "squatters", the "sooners", and the "boomers" have always urged the opening of our Indian reservations. But the missionaries always knew the danger, and they always resisted secularization until their work was finished. Sooner or later, however, with the disappearance of frontier conditions, the missionary was expected to move on. His religious task was beside the soldier, entre infieles, in the outposts of civilization.

But the missionaries were not alone religious agents. Designedly in part, and incidentally in part, they were political and civilizing agents of a very positive sort, and as such they constituted a vital feature of Spain's pioneering system. From the standpoint of the Church, and as viewed by themselves, their principal work 
was to spread the Faith, first, last, and always. To doubt this is to confess complete and disqualifying ignorance of the great mass of existing missionary correspondence, printed and unprinted, so fraught with unmistakable proofs of the religious zeal and devotion of the vast majority of the missionaries. It is quite true, as Engelhardt says, that they "came not as scientists, as geographers, as school-masters, nor as philanthropists, eager to uplift the people in a worldly sense, to the exclusion or neglect of the religious duties pointed out by Christ". But it is equally true, and greatly to their credit, that, incidentally from their own standpoint and designedly from that of the government, they were all these and more, and that to all these and other services they frequently and justly made claim, when they asked for government aid.

The missions, then, were agencies of the State as well as of the Church. They served not alone to Christianize the frontier, but also to aid in extending, holding, and civilizing it. Since Christianity was the basic element of European civilization, and since it was the acknowledged duty of the State to extend the Faith, the first task of the missionary, from the standpoint of both State and Church, was to convert the heathen. But neither the State nor the Church-nor the missionary himself-in Spanish dominions, considered the work of the mission as ending here. If the Indian were to become either a worthy Christian or a desirable subject, he must be disciplined in the rudiments of civilized life. The task of giving the discipline was likewise turned over to the missionary. Hence, the missions were designed to be not only Christian seminaries, but in addition were outposts for the control and training schools for the civilizing of the frontier.

Since they served the State, the missions were supported by the State. It is a patent fact, and scarcely needs demonstrating, that they were maintained to a very considerable extent by the royal treasury. The Franciscan missions of New Spain in the eighteenth century had four principal means of support. The annual stipends of the missionaries (the sinodos) were usually paid by the government. These sinodos varied in amount according to the remoteness of the missions, and on the northernmost frontier were usually $\$ 450$ for each missionary. In I758, for example, the treasury of New Spain was annually paying sinodos for twelve Querétaran friars in Coahuila and Texas, six Jaliscans in Coahuila, eleven Zacatecans in Texas, ten Fernandinos in the Sierra Gorda, six Jaliscans in Nayarit, twenty-two Zacatecans in Nuevo León and Nueva Vizcaya, seventeen Zacatecans in Nuevo Santander, five 
San Diegans in Sierra Gorda, and thirty-four friars of the Provincia del Santo Evangelio in New Mexico, or, in all, I23 friars, at an average of about 350 pesos each. This report did not include the Provincia de Campeche or the Yslas de Barlovento, for which separate reports had been asked. Other appropriations were made for missionaries in the Marianas and the Philippine Islands, dependencies of New Spain.

Besides the sinodos, the government regularly furnished the missionaries with military protection, by detaching from the near-by presidios from two to half a dozen or more soldiers for each mission. In addition, the royal treasury usually made an initial grant (ayuda de costa) of \$1000 to each mission, to pay for bells, vestments, tools, and other expenses of the founding, and in cases of emergency it frequently made special grants for building or other purposes.

These government subsidies did not preclude private gifts, or alms, which were often sought and secured. In the founding, of new missions the older establishments were expected to give aid, and if able they did respond in liberal measure. And then there were endowments. The classic examples of private endowments on the northern frontier were the gifts of Don Pedro de Terreros, later Conde de Regla, who offered $\$$ I 50,000 to found Apache missions in Coahuila and Texas, and the Jesuit Fondo Piadoso, or Pious Fund, of California. This latter fund, begun in I697, grew by a variety of gifts to such an amount that the missions of Lower California were largely supported by the increase alone. With the expulsion of the Jesuits in 1767 the fund was taken over by the government, and became the principal means of support of the new Franciscan missions of Alta California, besides being devoted in part to secular purposes. Even in Alta California, however, the royal treasury paid the wages (sueldos) of the mission guards, and gave other financial aid.

Finally, the Indians of the missions were expected soon to become self-supporting, and, indeed, in many cases they did acquire large wealth through stock-raising and agricultural pursuits. But not a penny of this belonged to the missionaries, and the annual sinodos, or salaries, continued to be paid from other sources, from the Pious Fund in California, and from the royal treasury generally elsewhere.

While it is thus true that the missions were supported to a very considerable degree by the royal treasury, it is just as plain that the amount of government aid, and the ease with which it was secured, 
depended largely upon the extent to which political ends could be combined with religious purposes.

The importance of political necessity in loosening the royal purse-strings is seen at every turn in the history of Spanish North America. Knowing the strength of a political appeal, the friars always made use of it in their requests for permission and aid. While the monarchs ever used pious phrases, and praised the work of the padres-without hypocrisy no doubt-the royal pocketbook was not readily opened to found new missions unless there was an important political as well as a religious object to be gained.

Striking examples of this fact are found in the histories of Texas and California. The missionaries of the northern frontier had long had their eyes on the "Kingdom of the Texas" as a promising field of labor, and had even appealed to the government for aid in cultivating it. But in vain, till La Salle planted a French colony' at Matagorda Bay. Then the royal treasury was opened, and funds were provided for missions in eastern Texas. The French danger passed for the moment, and the missions were withdrawn. Then for another decade Father Hidalgo appealed in vain for funds and permission to re-establish the missions. But when St. Denis, agent of the French governor of Louisiana, intruded himself into Coahuila, the Spanish government at once gave liberal support for the refounding of the missions, to aid in restraining the French.

The case was the same for California. Since the time of Vizcaino the missionaries had clamored for aid and for permission to found missions at San Diego and Monterey. In I620 Father Ascension, who had been with Vizcaíno eighteen years before, wrote, "I do not know what security His Majesty can have in his conscience for delaying so long to send ministers of the Gospel to this realm of California", and, during the next century and a half, a hundred others echoed this admonition. But all to no purpose till the Russian Bear began to amble or to threaten to amble down the Pacific Coast. Then money was forthcoming-partly from the confiscated Pious Fund, it is true-and then missionaries were sent to help hold the country for the crown. On this point Father Engelhardt correctly remarks:

The missionaries, who generally offered to undergo any hardships in order to convert the Indians, appear to have been enlisted merely for the purpose of securing the territory for the Spanish king ... [and] the Spanish government would not have sent ships and troops to the northwest if the Russians had not crept down the Pacific coast. ....

The men who presumed to guide the destinies of Spain then, and,

AM. HIST. REV., vOL. XXIII.-4. 
as a rule ever since, cared not for the success of Religion or the welfare of its ministers except in so far as both could be used to promote political schemes.

In this last, I think, Father Engelhardt is too hard on the Spanish monarchs. Their pious professions were not pure hypocrisy. They were truly desirous of spreading the Faith. But they were terribly "hard up", and they had little means to support religious projects unless they served both political and religious ends.

The value of the missionaries as frontier agents was thus clearly recognized, and their services were thus consciously utilized by the government. In the first place, they were often the most useful of explorers and diplomatic agents. The unattended missionary could sometimes go unmolested, and without arousing suspicion and hostility, into districts where the soldier was not welcome, while by their education and their trained habits of thought they were the class best fitted to record what they saw and to report what should be done. For this reason they were often sent alone to explore new frontiers, or as peace emissaries to hostile tribes, or as chroniclers of expeditions led by others. Hence it is that the best of the diaries of early exploration in the Southwest-and, indeed, in most of America-were written by the missionaries.

As illustrations of this kind of frontier service on the part of the missionaries we have but to recall the example of Friar Marcos, who was sent by Viceroy Mendoza to seek the rumored "Seven Cities" in New Mexico; the rediscovery of that province, under the viceroy's patronage, by the party led by Fray Agustin Rodríguez; the expeditions of Father Larios, unattended, into Coahuila; the forty or more journeys of Father Kino across the deserts of Sonora, and his demonstration that California was a peninsula, not an island, as most men had thought; the part played by Kino in pacifying the revolt of the Pimas in 1695, and in making the frontier safe for settlers; the diplomatic errands of Fathers Calahorra and Ramirez, sent by the governors of Texas to the hostile northern tribes; the lone travels of Father Garcés, of two thousand miles or more, over the untrod trails, in Arizona, California, and New Mexico, seeking a better route to California; and the expedition of Fathers Domínguez and Escalante, pathfinders for an equal distance in and about the Great Basin between the Rockies and the Sierras.

The missions served also as a means of defense to the king's dominions. This explains why the government was more willing to support missions when the frontier needed defending than at other 
times, as in the cases, already cited, of Texas and California. It is significant, too, in this connection, that the Real Hacienda, or Royal Fisc, charged the expenses for presidios and missions both to the same account, the Ramo de Guerra, or "War Fund". In a report for New Spain made in $175^{8}$ a treasury official casually remarked,

Presidios are erected and missions founded in tierra firme whenever it is necessary to defend conquered districts from the hostilities and invasions of warlike, barbarian tribes, and to plant and extend our Holy Faith, for which purposes juntas de guerra y hacienda are held.

It is indeed true that appropriations for missions were usually made and that permission to found missions was usually given in councils of war and finance.

The missionaries counteracted foreign influence among their neophytes, deterred them from molesting the interior settlements, and secured their aid in holding back more distant tribes. Nearly every army that was led from San Antonio, Texas, in the eighteenth century, against the hostile Apaches and Comanches, contained a strong contingent of mission Indians, who fought side by side with the Spaniards. Father Kino was relied upon by the military leaders of Sonora to obtain the aid of the Pimas, his beloved neophytes, in defense of the Sonora settlements. When he was assigned to California, in company with Salvatierra, the authorities of Sonora protested, on the ground that, through his influence over the natives, he was a better means of protection to the province than a whole company of soldiers. When a Spanish expedition was organized to attack the Apaches, Kino was sent ahead to arouse and enlist the Pima allies. When the Pimas put the Apaches to flight, it was Kino to whom they sent the count of the enemy's dead, recorded by notches on a pole; on the same occasion it was Kino who received the thanks of citizens and officials of the province; and, when doubt was expressed as to what the Pimas had accomplished, it was Kino who rode a hundred miles or more to count the scalps of the vanquished foe, as evidence with which to vindicate his Pima friends.

The very mission plants were even built and often served as fortresses, not alone for padres and neophytes, but for near-by settlers, too. Every well-built mission was ranged round a great court or patio, protected on all sides by the buildings, whose walls were sometimes eight feet thick. In hostile countries these buildings were themselves enclosed within massive protecting walls. In I740 President Santa Ana wrote that Mission Valero, at San Antonio, Texas, was better able to withstand a siege than any 
of the three presidios of the province. This of course was only a relative excellence. Twenty-two years later the same mission was surrounded by a wall, and over the gate was a tower, equipped with muskets, ammunition, and three cannon. At the same time the mission of San José (Texas) was called "a castle" which more than once had been proof against the Apaches.

Not only were the missionaries consciously utilized as political agents to hold the frontier but they often served, on their own motion, or with the co-operation of the secular authority, as "promoters" of the unoccupied districts. They sent home reports of the outlying tribes, of the advantages of obtaining their friendship, of the danger of foreign incursions, of the wealth and attractions of the country, and of the opportunities to extend the king's dominion. Frequently, indeed, they were called to Mexico, or even to Spain, to sit in the royal councils, where their expert opinions often furnished the primary basis of a decision to occupy a new outpost. As examples of this, near at home, we have but to recall Escobar, Benavides, and Ayeta of New Mexico, Massanet, Hidalgo, and Santa Ana of Texas, Kino of Lower California, and Serra of Alta California. Thus consciously or unconsciously, directly or indirectly, with or without secular initiative, the missionaries served as most active promoters, one might even call them "boosters", of the frontier.

But the missionaries helped not only to extend and hold and promote the frontier; more significantly still, they helped to civilize it. And this is the keynote of my theme. Spain possessed high ideals, but she had peculiar difficulties to contend with. She laid claim to the lion's share of the two Americas, but her population was small and little of it could be spared to people the New World. On the other hand, her colonial policy, equalled in humanitarian principles by that of no other country, perhaps, looked to the preservation of the natives, and to their elevation to at least a limited citizenship. Lacking Spaniards to colonize the frontier, she would colonize it with the aborigines. Such an ideal called not only for the subjugation and control of the natives, but for their civilization as well. To bring this end about the rulers of Spain again made use of the religious and humanitarian zeal of the missionaries, choosing them to be to the Indians not only preachers, but also teachers and disciplinarians. To the extent that this work succeeded it became possible to people the frontier with civilized natives, and thus to supply the lack of colonists. This desire was quite in harmony with the religious aims of the friars, who found temporal discipline indispensable to the best work of Christianization. 
Hence it is that in the Spanish system-as distinguished from the French, for example-the essence of the mission was the discipline, religious, moral, social, and industrial, which it afforded. The very physical arrangement of the mission was determined with a view to discipline. The central feature of every successful mission was the Indian village, or pueblo. The settled tribes, such as the Pueblo Indians of New Mexico, or the Pimas of Arizona, could be instructed in their native towns, but wandering and scattered tribes must be assembled and established in pueblos, and kept there, by force if necessary. The reason why the missions of eastern Texas failed was that the Indians refused to settle in pueblos, and without more soldiers than were available it was impossibie to control them. It was on this question that Father Serra split with Governor Neve regarding the Santa Barbara Indians in California. To save expense for soldiers, Neve urged that the friars should minister to the Indians in their native rancherias. But the missionaries protested that by this arrangement the Indians could not be disciplined. The plan was given up therefore, and instead the Indians were congregated in great pueblos at San Buenaventura and Santa Barbara. Thus, the pueblo was essential to the mission, as it had been to the encomienda.

Discipline called for control, and this was placed largely in the hands of the missionaries. The rule was two friars for each mission, but in many instances there was only one. The need of more was often urged.

As a symbol of force, and to afford protection for missionaries and mission Indians, as well as to hold the frontier against savages and foreigners, presidios, or garrisons, were established near by. And thus, across the continent, from San Agustin to San Francisco, stretched a long and slender line of presidios-San Agustín, Apalache, Pensacola, Los Adaes, La Bahía, San Antonio, San Juan Bautista, Rio Grande, San Sabá, El Paso, Santa Fé, Janos, Fronteras, Terrenate, Tubac, Altár, San Diego, Santa Barbara, Monterey, and San Francisco-a line more than twice as long as the RhineDanube frontier held by the Romans, from whom Spain learned her lesson in frontier defense.

To assist the missionaries in their work of disciplining and instructing the neophytes, each mission was usually provided with two or more soldiers from the nearest presidio. To help in recovering runaways-for the Indians frequently did abscond-special detachments of soldiers were furnished. The impression is often given that the missionaries objected to the presence of soldiers at the mis- 
sions, but as a rule the case was quite the contrary. What they did object to was unsuitable soldiers, and outside interference in the selection and control of the guard. It is true, indeed, that immoral or insubordinate soldiers were deemed a nuisance, and that since the presidials were largely half-breeds-mestizoes or mulattoes-and often jailbirds at that, this type was all too common. But in general military aid was demanded, and complaint of its inadequacy was constantly made. On this point the testimony of Fray Romualdo Cartagena, guardian of the College of Santa Cruz de Querétaro, is valid. In a report made in 1772 , still in manuscript, he wrote,

What gives these missions their permanency is the aid which they receive from the Catholic arms. Without them pueblos are frequently abandoned, and ministers are murdered by the barbarians. It is seen every day that in missions where there are no soldiers there is no success, for the Indians, being children of fear, are more strongly appealed to by the glistening of the sword than by the voice of five missionaries. Soldiers are necessary to defend the Indians from the enemy, and to keep an eye on the mission Indians, now to encourage them, now to carry news to the nearest presidio in case of trouble. For the spiritual and temporal progress of the missions two soldiers are needed, for the Indians cannot be trusted, especially in new conversions.

Bancroft Library

This is the testimony of missionaries themselves. That protection was indeed necessary is shown by the martyrdom of missionaries on néarly every frontier-of Father Segura and his entire band of Jesuits in Virginia in I 570 ; of Father Saeta in Sonora; of Fathers Ganzábal, Silva, Terreros, and Santiesteban in Texas; of Fathers Carranco and Tamaral in Lower California; of Father Luis Jayme at San Diego (Alta California); of Father Garcés and his three companions at Yuma, on the Colorado ; and of the twentyone Franciscans in the single uprising in New Mexico in I680. But these martyrdoms were only occasional, and the principal business of the soldiers was to assist the missionaries in disciplining and civilizing the savages.

As teachers, and as an example to new converts, it was the custom to place in each new mission three Indian families from the older missions. After a time the families might return to their homes. As Father Romualdo remarked: "It is all the better. if these families be related to the new, for this insures the permanence of the latter in the missions, while if they do flee it is easier to recover them by means of their relatives than throughrstrangers."

Notable among the Indians utilized as teachers and colonists in the northern missions were the Tlascaltecans, of Tlascala, the native city of Mexico made famous by Prescott. Having been subdued 
by Cortés, the Tlascaltecans became the most trusted supporters of the Spaniards, as they had been the most obstinate foes of the "Triple Alliance", and, after playing an important part in the conquest of the Valley of Mexico, they became a regular factor in the extension of Spanish rule over the north country. Thus, when San Luis Potosí had been conquered, colonies of Tlascaltecans were set to teach the more barbarous natives of that district both loyalty to the Spaniards and the elements of civilization. In Saltillo a large colony of Tlascaltecans was established by Urdiñola at the end of the sixteenth century, and became the mother colony from which numerous offshoots were planted at the new missions and villages further north. At one time a hundred families of Tlascaltecans were ordered sent to Pensacola; in I755 they figured in the plans for a missionary colony on the Trinity River, in Texas; two years later a little band of them were sent to the San Sabá mission in western Texas to assist in civilizing the Apaches; and twenty years afterward it was suggested that a settlement, with these people as a nucleus, be established far to the north, on the upper Red River, among the Wichita Indians of Texas and Oklahoma. To help in civilizing the mission Indians of Jalisco, Sinaloa, and Sonora, the Tarascans of Michoacán were utilized; further north, the Opatas, of southern Sonora, were sent into Arizona as teachers of the Pimas; to help in civilizing the Indians of California, Serra brought mission Indians from the Peninsula.

Discipline and the elements of European civilization were imparted at the missions through religious instruction, through industrial training, and, among more advanced natives, by means of rudimentary teaching in arts and letters.

$\Gamma$ Every mission was, in the first place, a Christian seminary, designed to give religious discipline. Religious instruction, of the elementary sort suited to the occasion, was imparted by a defirite routine, based on long experience, and administered with much practical sense and regard for local conditions.

Aside from the fundamental cultural concepts involved in Christianity, this religious instruction in itself involved a most important means of assimilation. By the laws of the Indies the missionaries were enjoined to instruct the neophytes in their native tongues, and in the colleges and seminaries professorships were established to teach them. But it was found that, just as the natives lacked the concepts, the Indian languages lacked the terms in which properly to convey the meaning of the Christian doctrine. Moreover, on some frontiers there were so many dialects that it was impossible for the friars to learn them. This was pre-eminently true of the 
lower Rio Grande region, where there were over two hundred dialects, more than twenty of which were quite distinct. On this point Father Ortiz wrote in 1745 :

The ministers who have learned some language of the Indians of these missions assert that it is impossible to compose a catechism in their idiom, because of the lack of terms in which to explain matters of Faith, and the best informed interpreters say the same. There are as many languages as there are tribes, which in these missions aggregate more than two hundred... . Although they mingle and understand each other to some extent, there are twenty languages used commonly by the greater number of the tribes. And since they are new to us, and there are no schools in which to learn them, and since the Fathers are occupied with ministering to the spiritual and temporal needs of the Indians, and in recovering those who flee, the Fathers can hardly be held blameworthy for not learning the native languages.

For these reasons, on the northern frontier instruction was usually given in Spanish, through interpreters at first, and directly as soon as the Indians learned the language of the friars. In the case of children, who were the chief consideration, this was quickly done. And thus incidentally a long step toward assimilation was accomplished, for we all know the importance of language in the fusing of races and cultures. The firmness of the hold of the Spanish language upon any land touched by Spain, however lightly, has often been noted. It was partly, or even largely, due to this teaching of the native children at the missions.

The routine of religious discipline established by the Franciscans in the missions taken over from the Jesuits in Sonora, in 1767 , was typical of all the Franciscan missions, and was not essentially different from that of the other orders. It was described by Father Reyes, later Bishop Reyes, as follows:

Every day at sunrise the bells call the Indians to Mass. An old Indian, commonly called mador, and two fiscales, go through the whole pueblo, requiring all children and unmarried persons to go to the church, to take part in the devotion and silence of the Mass. This over, they repeat in concert, in Spanish, with the minister, the prayers and the Creed. At sunset this exercise is repeated at the door of the church, and is concluded with saying the rosary and chanting the salve or the alavado. The mador and the fiscales are charged, on Sundays and feast days, to take care to require all men, women, and children to be present at Mass, with their poor clothes clean, and all washed and combed.

The very act of going to church, then, involved a lesson in the amenities of civilization. There was virtue then as now in putting on one's "Sunday clothes".

On these days [Father Reyes continues] Mass is chanted with harps, violins [all played by the natives], and a choir of from four to six [native] men and women. In Lent all have been required to go to Mass daily.... 
On Palm Sunday, at the head missions (cabeceras), that feast is observed with an image and processions. After Easter, censuses are made to ascertain what ones have complied with the Church. In the first years it seemed impossible to us missionaries to vanquish the rudeness of the Indians, and the difficulties of making them confess, and of administering communion. But lately all the young men and some of the old have confessed. In the principal pueblos, where the missionaries reside, many attend the sacraments on feast days. On the Day of Santa Maria the rosary is sung through the pueblo. On other occasions they are permitted to have balls, diversions, and innocent games. But because they have attempted to prohibit superstitious balls and the scalp dance, the missionaries have encountered strong opposition from the [secular] superiors of the province, who desire to let the Indians continue these excesses.

They contributed, no doubt, to the war spirit, and thus to the defense of the province against the Apaches.

If the mission was a Christian seminary, it was scarcely less an industrial training school. Father Engelhardt writes:

It must be remembered that the friars came to California as messengers of Christ. They were not farmers, mechanics, or stock breeders. Those who, perhaps, had been engaged in such pursuits, had abandoned them for the higher occupation of the priest of God, and they had no desire to be further entangled in worldly business. In California, however [and he might have added, quite generally] the messengers of the Gospel had to introduce, teach, and supervise those very arts, trades, and occupations, before they could expect to make any headway with the truths of salvation. ... As an absolutely necessary means to win the souls of the savages, these unworldly men accepted the disagreeable task of conducting huge farms, teaching and supervising various mechanical trades, having an eye on the livestock and herders, and making ends meet generally.

The civilizing function of the typical Spanish mission, where the missionaries had charge of the temporalities as well as of the spiritualities, was evident from the very nature of the mission plant. While the church was ever the centre of the establishment, and the particular object of the minister's pride and care, it was by no means the larger part. Each fully developed mission was a great industrial school, of which the largest, as in California, sometimes managed more than 2000 Indians. There were weaving rooms, blacksmith shop, tannery, wine-press, and warehouses; there were irrigating ditches, vegetable gardens, and grain fields; and on the ranges roamed thousands of horses, cattle, sheep, and goats. Training in the care of fields and stock not only made the neophytes self-supporting, but afforded the discipline necessary for the rudiments of civilized life. The women were taught to cook, sew, spin, and weave; the men to fell the forest, build, run the forge, tan leather, make ditches, tend cattle, and shear sheep. 
Even in New Mexico, where the missionaries were not in charge of the temporalities-that is, of the economic interests of the Indians-and where the Indians had a well-established native agriculture, the friars were charged with their instruction in the arts and crafts, as well as with their religious education. And when the custodian, Father Benavides-later Bishop of Goa-wrote in 1630, after three decades of effort by the friars in that province, he was able to report fourteen monasteries, serving fifty-odd pueblos, each with its school, where the Indians were all taught not only to sing, play musical instruments, read, and writę; but, as Benavides puts it, "all the trades and polite deportment", ail imparted by "the great industry of the Religious who converted them".

In controlling, supervising, and teaching the Indians, the friars were assisted by the soldier guards, who served as mayor domos of the fields, of the cattle and horse herds, of the sheep and goat ranches, and of the shops. In the older missions, even among the most backward tribes, it sometimes became possible to dispense with this service, as at San Antonio, Texas, where, it was reported in 1772 , the Indians, once naked savages who lived on cactus apples and cotton-tail rabbits, had become so skilled and trustworthy that "without the aid of the Spaniards they harvest, from irrigated fields, maize, beans, and cotton in plenty, and Castilian corn for sugar. There are cattle, sheep, and goats in abundance", all being the product of the care and labor of the natives.

The results of this industrial training at the missions were to be seen in the imposing structures that were built, the fertile farms that were tilled, and the great stock ranches that were tended, by erstwhile barbarians, civilized under the patient discipline of the missionaries, assisted by soldier guards and imported Indian teachers, not in our Soüthwest alone, but on nearly every frontier of Spanish America.

The missionaries transplanted to the frontiers and made known to the natives almost every conceivable domestic plant and animal of Europe. By requiring the Indians to work three days a week at community tasks, the Jesuits in Pimería Alta-to give a particular illustration-established at all the missions flourishing ranches of horses, cattle, sheep, and goats, and opened fields and gardens for the cultivation of a vast variety of food plants. Kino wrote in I7 10 of the Jesuit missions of Sonora and Arizona,

There are already thrifty and abundant fields ... of wheat, maize, frijoles, chickpeas, beans, lentils, bastard chickpeas (garabanzas), etc. There are orchards, and in them vineyards for wine for the Masses; and fields of sweet cane for syrup and panocha, and with the favor of Heaven, before long, for sugar. There are many Castilian fruit trees, 
such as figs, quinces, oranges, pomegranates, peaches, apricots, pears, apples, mulberries, etc., and all sorts of garden stuff, such as cabbage, lettuce, onions, garlic, anise, pepper, mustard, mint, etc.

Other temporal means [he continues] are the plentiful ranches, which are already stocked with cattle, sheep, and goats, many droves of mares, horses, and pack animals, mules as well as horses, for transportation and commerce, and very fat sheep, producing much tallow, suet, and soap, which is already manufactured in abundance.

An illustration of some of the more moderate material results is to be had in the following description of the four Querétaran missions in Texas, based on an official report made in 1762 .

Besides the church, each mission had its convento, or monastery, including cells for the friars, porter's lodge, refectory, kitchen, offices, workshops, and granary, usually all under a common roof and ranged round a patio. At San Antonio de Valero the convento was a two-story structure fifty varas square with two patios and with arched cloisters above and below. The others were similar.

An important part of each mission was the workshop, for here the neophytes not only helped to supply their economic needs, but got an important part of their training for civilized life. At each of these four missions the Indians manufactured mantas, terlingas, sayales, rebozos, frezadas, and other common fabrics of wool and cotton. At Mission San Antonio the workshop contained four looms, and two store-rooms with cotton, wool, cards, spindles, etc. At Concepción and San Francisco there were three looms each.

The neophytes of each mission lived in an Indian village, or pueblo, closely connected with the church and monastery. Of those of the four Querétaran missions we have the fullest description of the pueblo at Mission San Antonio de Valero. It consisted of seven rows of houses built of stone, with arched porticoes, doors, and windows. There was a plaza through which ran a water-ditch, grown with willows and fruit trees. Within the plaza was a curbed well, to supply water in case of a siege by the enemy. The pueblo was surrounded by a wall, and over the gate was a tower, with embrasures, and equipped with three cannon, firearms, and ammunition. The houses were furnished with high beds, chests, metates, pots, kettles, and other domestic utensils. The pueblo of San Antonio was typical of all.

Agricultural and stock-raising activities had increased since 1745 . At the four Querétaran missions there were now grazing 4897 head of cattle, 12,000 sheep and goats, and about 1600 horses, and each mission had from thirty-seven to fifty yoke of working oxen. Of the four missions San Francisco raised the most stock, having 2262 head of cattle and 4000 sheep and goats. Each mission had its 
ranch, some distance away, where the stock was kept, with one or more stone houses, occupied by the families of the overseers; the necessary corrals, farming implements, and carts ; and tools for carpentry, masonry, and blacksmithing. Each mission had well-tilled fields, fenced in and watered by good irrigating ditches, with stone dams. In these fields maize, chile, beans, and cotton were raised in abundance, and in the huertas a large variety of garden truck.

This picture of the Texas missions is interesting, but in magnitude the establishments described are not to be compared with those in Paraguay or even in California, where, in 1834 , on the eve of the destruction of the missions, 31,000 mission Indians at twentyone missions herded 396,000 cattle, 62,000 horses, and 321,000 hogs, sheep, and goats, and harvested I23,000 bushels of grain, and where corresponding skill and industry were "shown by the neophytes in orchard, garden, wine-press, loom, shop, and forge.

The laws of the Indies even prescribed and the missions provided a school for self-government, elementary and limited, it is true, but germane and potential nevertheless. This was effected by organizing the Indians of the missions into a pueblo, with civil and military officers, modelled upon the Spanish administration. When the mission was founded the secular head of the district-governor, captain, or alcalde-as representative of the king, formally organized the pueblo, appointed the native officers, and gave title to the four-league grant of land. In constituting the native government, wisdom dictated that use should be made of the existing Indian organization, natives of prestige being given the important offices. Thereafter the civil officers were chosen by a form of native election, under the supervision of the missionary, and approved by the secular head of the jurisdiction.

The civil officers were usually a governor, captain, alcaldes, and alguacil, who by law constituted a cabildo, or council. The military officers were a captain or a teniente, and subalterns, and were appointed by the secular head, or by a native captain-general subject to approval by the secular head. The military officers had their own insignia, and, to give them prestige, separate benches were placed in the churches for the governor, alcalde, and council. In Sonora there was a topil, whose duty was to care for the community houses -a sort of free hostelry, open to all travellers, which seems to have been of native rather than of Spanish origin. The Indians had their own jail, and inflicted minor punishments, prescribed by the minister. Indian overseers kept the laborers at their work and, indeed, much of the task of controlling the Indians was effected through Indian officers themselves. Of course it was the directing 
force of the padres and the restraining force of the near-by presidio which furnished the ultimate pressure.

This pueblo government was established among the more advanced tribes everywhere, and it succeeded in varying degrees. It was often a cause for conflict of jurisdiction, and in California where the natives were of the most barbarous, it was strongly opposed by the missionaries. It has been called a farce, but it certainly was not so intended. It was not self-government any more than is student government in a primary school. But it was a means of control, and was a step toward self-government. It is one of the things, moreover, which help to explain how two missionaries and three or four soldiers could make an orderly town out of two or three thousand savages recently assembled from divers and sometimes mutually hostile tribes. So deeply was it impressed upon the Indians. of New Mexico that some of them yet maintain their Spanish pueblo organization, and by it still govern themselves, extra-legally. And, I am told, in some places even in California, the descendants of the mission Indians still keep up the pueblo organization as a sort of fraternity, or secret society.

In these ways, then, did the missions serve as frontier agencies of Spain. As their first and primary task, the missionaries spread the Faith. But in addition, designedly or incidentally, they explored the frontiers, promoted their occupation, defended them and the interior settlements, taught the Indians the Spanish language, and disciplined them in good manners, in the rudiments of European crafts, of agriculture, and even of self-government. Moreover, the missions were a force which made for the preservation of the Indians, as opposed to their destruction, so characteristic of the Anglo-American frontier. In the English colonies the only good Indians were dead Indians. In the Spanish colonies it was thought worth while to improve the natives for this life as well as for the next. Perhaps the missions did not, in every respect, represent a twentieth-century ideal. Sometimes, and to some degree, they failed, as has every human institution. Nevertheless, it must not be forgotten that of the millions of half-castes living south of $u$, the grandparents, in a large proportion of cases, at some generation removed, on one side or the other, were once mission Indians, and as such learned the elements of Spanish civilization. For these reasons, as well as for unfeigned religious motives, the missions received the royal support. They were a conspicuous feature of Spain's frontiering genius.

Herbert E. Bolton. 

